\title{
The Effect of Social Security on Saving
}

\author{
by Martin Feldstein *
}

\section{Introduction}

The saving rate of an economy is one of the most important parameters governing its long-run performance. A higher saving rate means greater capital intensity, higher productivity and a better standard of living. An economy that increases its saving rate experiences more rapid technical progress and a faster rate of growth over many years until a new equilibrium is established.

Saving rates differ very substantially among industrial nations. For the 15 year period from 1960 through 1974, gross saving accounted for an average of 25 percent of gross domestic product among the 21 O.E.C.D. countries for which data are available. But this gross saving rate ranged from a high of 37.2 percent in Japan to lows of 18.4 percent and 18.6 percent for the U.K. and the U.S. The pattern of high and low saving rate countries has remained quite stable over this period. The correlation between the average saving rate in a country in the 1960-64 period and the 1965-69 period is 0.97. For 1965-69 and 1970-74, the correlation is 0.93 (Feldstein and Horioka, 1979).

Why do saving rates differ so much among countries? How do the government policies pursued in each country affect that country's saving rate ? As a profession, we are still disturbingly far from having complete answers to these very important questions. My remarks today will focus on one aspect of this subject that, after several years of research, I believe is extremely important : the impact of social security on private savings.

Social security programs have become extremely important in most of the industrial countries of the world. Social security benefits have come to be relied upon as the major source of finance of post-retirement consumption in the United States and in many other countries. The traditional life cycle theory of saving implies that existing social security programs are likely to depress substantially the aggregate private rate of saving. Moreover, since the social security programs are largely

* Professor of Economics, Harvard University, and President, National Bureau of Economic Research. This paper draws together conclusions of research done as part of the NBER's program of research on Social Insurance and its special research project on Capital Formation. It was presented as the Third Annual Lecture of the Geneva Association, at the Institut d'Etudes Politiques in Paris, on 15 January 1980. It was also presented as the Frank Paish Lecture at the Annual Meeting of the British Association of University Teachers in Economics. The views expressed here are personal and should not be attributed to any organization. 
unfunded - i.e., they do not accumulate assets to meet future benefit obligations in the way that a private pension would - the reduction in the private saving rate translates into a corresponding reduction in the national saving rate. But as with so many other subjects, a wider and more general analytic framework reveals a theoretical indeterminacy; we cannot know on the basis of a priori consideration alone whether social security increases or decreases the private saving rate. I will discuss the nature of this theoretical indeterminacy in the first part of my lecture.

There is fortunately a growing body of empirical research on this subject. While there are of course ambiguities and problems in the interpretation of these econometric studies, I believe that on balance the evidence strongly supports the implication of the traditional life cycle saving theory that the provision of a large social security pension does substantially reduce real private saving. The second half of my lecture will provide a review of this evidence.

\section{Social security in the theory of saving}

The life cycle model is the central idea in the modern theory of saving because it provides the crucial link between the microeconomics of rational household behavior and the macroeconomics of the rate of saving. The fundamental insight of this theory, that aggregate saving is positive in a growing economy because the younger workers who save are more numerous and have higher earnings than the older retirees who dissave, was presented by Sir Roy Harrod in the second lecture of his famous book, Towards a Dynamic Economics [1948]. Harrod's description of the household's optimizing behavior, which he noted was an extension of Irving Fisher's [1930] analysis, is remarkably modern and "neoclassical" for someone who is rightly regarded as one of the great developers of Keynesian economic theory. It was then Franco Modigliani and his collaborators [e.g., 1954, 1957, 1963, and 1966] who developed Harrod's insight and metaphor of "hump saving" into a quantitative theory and began the process of empirical verification that has made the life cycle model a central feature of our economic understanding.

\subsection{Implications of the life cycle model}

The traditional Harrod-Modigliani life cycle model implies that the introduction of an actuarially fair social security pension program unambiguously reduces private saving. More specifically, in this life-cycle framework, a government policy alters the time pattern of consumption only if it changes the household's lifetime budget constraint. Since an actuarially fair social security program leaves the budget constraint unchanged, there is also no change in each year's consumption. The social security tax that is paid in each year therefore reduces private saving by an equal amount. For an actuarially fair social security program, this is equivalent to reducing the personal wealth accumulated before retirement by the actuarial present value of future benefits (see Feldstein 1974, 1977).

In the United States, the substantial size of the social security program implies that the magnitude of this reduction in private saving is potentially very great. It is useful to review briefly the size of this potential life cycle effect before going on to discuss the possible offsetting effects suggested by a more general theoretical framework. 
Consider the question first from the point of view of an average American worker. A married worker who has had the median level of earnings all his life now retires with social security benefits for himself and his wife equal to 65 percent of his peak before-tax earnings. Since these social security benefits are untaxed, they replace approximately 80 percent of his maximum after-tax earnings. Moreover, the benefits are now permanently inflation-indexed so that they maintain their real value regardless of what happens to the price level. With such a high replacement rate, there is little if any reason for such a worker to want to save or to have a private pension.

The replacement rate is higher for workers with less than the median earnings and somewhat lower for workers with earnings above the median. Social security provides a significant replacement rate except for the relatively small number of employees who earn substantially more than the current maximum yearly earnings of nearly $\$ 23,000$. The replacement rate is also lower for families in which there is a second earner whose contribution to total family income is relatively large. It is these groups alone that still have some incentive for private saving.

For most American families, social security is the most important form of household "wealth." More precisely, the actuarial present value of the social security benefits to which they will be entitled at age 65 exceeds the value of all their other assets combined. A recent study at the National Bureau of Economic Research concluded that the aggregate value of this social security wealth exceeded $\$ 3.5$ trillion in 1978.1 To put this $\$ 3.5$ trillion of social security pseudo-wealth into perspective, it is useful to note that the most inclusive traditional measure of the total net worth of the private sector is less than $\$ 6$ trillion. If the current social security wealth had been saved and accumulated as real wealth instead, the stock of real capital would be more than 50 percent larger than it is today.

The potential importance of the social security program is also clear if we look at the volume of social security tax collections. Since social security taxes are widely regarded as a form of compulsory saving, it is interesting to compare the annual social security taxes with the annual volume of private saving. In 1978, social security tax payments by employees and employers exceeded $\$ 100$ billion. By comparison, total private saving (including corporate retained earnings and net pension contributions as well as individual saving) was also approximately $\$ 100$ billion. Thus if the social security tax payments would have been saved instead, the private saving rate would have been double its actual level.

\subsection{Departures from maximizing behavior}

These figures leave no doubt about the very large potential impact of social security on the process of capital accumulation if the traditional life cycle theory is an appropriate model of individual saving behavior. It has, however, been common in many popular discussions of social security policy to reject this picture of rational life cycle saving and its conclusion that social security depresses private saving (e.g., Meyers, 1965 ; Pechman, et al, 1968 ; and Schulz, 1974). Individuals are instead viewed

1 Martin Feldstein and Anthony Pellechio [1979]. The estimate of $\$ 3.5$ trillion refers to individuals over age 34 only. 
as myopic nonplanners who save in a haphazard way or not at all ; it is this failure to provide systematically for consumption in retirement that is the primary justification for social security. As a result of such myopia, the introduction of social security or an increase in its scale would have no offsetting effect on private saving.

It is also sometimes argued that much of existing wealth does not reflect life-cycle accumulation but is held in order to make future bequests. According to one form of this view, individuals receive bequests and then act as stewards of that wealth until they pass it on to their own heirs ; holding and increasing wealth is a matter of morality and honor, not of utility maximizing economic behavior. Wealth that is held or accumulated in this way will not be affected by social security.

There are undoubtedly some individuals whose saving behavior is largely haphazard and irrational. There are others who regard the spending of inherited wealth as morally wrong and who guide their own accumulation by a principle of stewardship rather than the life-cycle use of funds. I doubt that either form of behavior is as common as is sometimes claimed. In any case, such behavior among part of the population would reduce the effect of social security on savings but not eliminate it.

Some writers have even suggested that the provision of social security may actually cause some individuals to save more. This argument is based largely on the survey evidence of Katona [1965] and Cagan [1965] indicating that persons covered by private pensions did not save less and may have saved more than those persons not covered by pensions. Cagan explained his surprising results in terms of a "recognition effect," i.e., when an individual is forced to participate in a pension plan, he recognizes for the first time the importance of saving for his old age. Participation in a pension plan has an educational effect ; more formally, it changes the individual's utility function as he perceives it ex ante during his working years. Katona added to this a second explanation : the "goal gradient" hypothesis of psychological aspiration theory according to which " effort is intensified the closer one is to one's goal" (Katona, 1965, p. 4). In more conventional economic terms, this would imply that individual preferences are themselves a function of the opportunity set or of the initial position, a dramatic departure from the usual assumption of economic analysis.

\subsection{Extending the life cycle model}

A theoretical analysis that implies that social security may not depress personal saving need not rest on an assumption of irrational behavior, recognition effects or changing preferences. In an analysis that I called the "extended life cycle model" (Feldstein, 1974), I showed how individual life cycle saving could actually be increased by the introduction of social security or by an increase of social security benefits. The essential feature of that extended life cycle model is that the pattern of working and retirement is not fixed but that retirement and saving decisions are made jointly. This has the important implication that any exogenous variable can influence saving indirectly by altering retirement.

Social security and private pensions are likely to induce earlier retirement, because benefits are generally available only to those who are fully or partially retired. The resulting increase in the expected period of retirement will, as such, increase total saving during preretirement years. The net effect of social security or a private pension 
depends on the relative strengths of the "wealth replacement effect" of the traditional life cycle model and the "induced retirement effect" suggested by the extended life cycle model. An important implication of this is the possibility that the effect of social security of a private pension on saving is not monotonic ; at first, the induced retirement effect might dominate but then, as the probability of retirement reaches a natural maximum, further increases in retirement benefits depress private saving.

A different extension of the life cycle model, the introduction of intergenerational transfers, has recently been proposed by Robert Barro [1974], Levis Kochin [1974] and Merton Miller and Charles Upton [1974]. The extreme version of this theory implies that an actuarially fair social security program will have no effect on private saving. The essence of their argument is that the introduction of social security (or a change in an existing program) causes an offsetting change in private intergenerational transfers. To understand and evaluate this argument, it is useful to distinguish three alternative cases that might exist before the introduction or change in social security : (1) parents plan to and do leave positive bequests to their children ; (2) parents plan to and do receive substantial support from their children during retirement ; and (3) a corner solution with no significant intended bequests or gifts in either direction.

Consider first the case with planned bequests that was emphasized by Barro and the others who developed the current argument. The parent generation chooses an optimal life cycle plan which, because their children's utility enters their own utility function, includes making a bequest to their children. An increase in social security benefits entails a transfer from children (who will pay the future social security taxes) to the parents. This upsets the parents' initial equilibrium by reducing the effective net value of the bequests that parents make to their children. To counteract this, the parents must increase the size of their cash bequest by enough to offset the extra taxes that their children will pay. The extra saving for this enlarged bequest just offsets the reduced saving that would otherwise result from the larger social security benefits.

The process is actually more complex than this because each future generation also receives benefits that are in turn financed by their own children. But since the real rate of return on real capital exceeds the pseudo-return on social security taxes (Samuelson, 1958), each future generation is worse off under social security. Restoring the initial equilibrium requires the first generation of parents to provide an extra bequest that will in effect endow an annuity for all future generations to compensate them for this difference. Barro has shown that the extra saving to establish this endowment just offsets the reduced saving that would otherwise result from the larger social security benefits of the first generation.

This model of offsetting private bequests requires an unlikely degree of rational planning and foresight. More important, it is wrong to assume that parents who are concerned about the utility of their children will necessarily wish to leave bequests. A parent who believes that, because of generally rising productivity and real incomes, his children will be richer than himself, may well decide that the optimal "bequest" is negative, i.e., a transfer from his children to himself. Since this decision cannot be enforced, the "constrained optimum" for the parent is no bequest. This may remain the parent's chosen position after an increase in social security : the increase in social security could alter the parent's unconstrained optimum but have no effect on actual bequests. 
It is clear that, for the vast majority of the population and therefore for most social security recipients, there are no significant bequests to children even in the presence of our current social security system. There is no evidence that the typical retiree wishes to offset social security intergenerational transfers from young to old. To the extent that there is no induced offsetting private transfer, social security reduces saving by substituting for private wealth.

Some supporters of the theory of offsetting bequests have tried to broaden their argument to include such other parent-child transfers as the financing of the child's education, the child's consumption at home, and even the amount of parental attention given to the child. There is of course no evidence that any of these have responded to the increase in social security. Moreover, none of them involves the accumulation of physical capital. Thus even if social security did induce such offsetting transfers from parents to children in the form of education or increased childhood consumption, it would still be true that social security reduced real saving and capital accumulation.

Consider therefore the seemingly more plausible second mechanism by which changing intergenerational transfers could offset the basic effect of social security. In this case, parents make no bequests but, in the absence of social security, rely on their children to finance their retirement consumption. In the extreme form of this argument, our pay-as-you-go system of public social security replaces a private pay-asyou-go system of private intrafamily transfers. In this extreme case, social security has no effect on private saving precisely because no such saving would have occurred in the absence of social security. More generally, the effect of social security on saving is reduced to the extent that parents rely on children for part of their support in old age and expect their children to reduce their gifts by any increase in the amount of the social security benefits.

The survey evidence on gifts from children to retired parents shows that this second case is also of very limited importance (e.g., Wintworth and Motley, 1970). At no time in recent decades has more than a small fraction of retirees received gifts from their children; moreover, the average gift was extremely small in comparison to concurrent income levels or to the corresponding ratio of social security benefits to income today. I have recently analyzed the experience of older retirees whose total incomes, including social security benefits but excluding gifts received from children and others, is below the official poverty line (Feldstein and Bernheim, 1979). Even among this very low income group, only a small fraction receive gifts from their children and the value of these gifts is very small.

It is beyond belief that the current working generation would, in the absence of social security, have made gifts totalling nearly $\$ 100$ billion to retired parents in 1978 . Moreover, it seems reasonable to believe that, even without social security, the rise in incomes during the past few decades would have made most workers choose to finance their own retirement consumption rather than be dependent on the much lower level of voluntary support that their children might later provide.

The dominant form of behavior is therefore likely to be the "corner solution" in which there are neither bequests nor the general support of retirees by their children. Parents might like to receive gifts from their generally more affluent children but have no way to coerce such behavior. They therefore save to finance their own retire- 
ment consumption and reduce their saving when social security benefits are increased. The econometric evidence summarized below supports the conclusion that this "corner solution" case is more important than either of the two cases in which changes in private intergenerational transfers offset the savings effect of social security.

In addition to induced changes in retirement and in transfers between parents and children, there is a third way in which the character of private behavior may partly offset the depressing effect of social security. To some extent, social security substitutes for private pension plans. In the United States, many of these pension plans are only partly funded ; i.e., the expected present value of future pension benefits exceeds the value of the assets owned by the pension funds. To the extent that social security merely substitutes for unfunded private pensions, an increase in social security is only the substitution of an unfunded public program for an unfunded private one. There is, however, an important difference. An unfunded private pension is a net corporate liability and should, if correctly perceived by investors, depress the value of corporate equity by an equal amount. The equity owners of the company should respond to this reduction in their wealth by increasing their saving. More explicitly, the effect of a private pension on total saving will not depend on whether or not it is funded if the stock market is efficient in reflecting the full extent of the unfunded liability and if share owners are rational savers whose consumption level depends only on their real lifetime budget constraint.

Although the study of the effect of pensions on private saving is far from complete, a preliminary analysis of time series data on the relation between private pension accumulation and other forms of saving implies that private pensions have not altered the total volume of private saving in the United States (Feldstein, 1979). Moreover, studies of data for individual firms indicate that each dollar of unfunded vested pension liability reduces the market value of a firm's equity by approximately one dollar (Oldfield, 1977 ; Feldstein and Seligman, 1979). Taken together, these two analyses suggest that private pensions do reduce the direct saving by individual employees and that this is offset through increased pension funding and the saving by individual shareholders. The combination of pension funding and induced shareholder response makes private pensions fundamentally different from social security and imply that substituting social security for private pensions is likely to depress total saving. Again, however, this is not a fully settled issue and is not one on which a priori arguments are fully convincing.

Even if we disregard the role of pensions as well as any induced changes in retirement and in private intergenerational transfers, there are reasons why rational savers might not regard "social security wealth" - i.e., the present actuarial value of future social security benefits - and ordinary private fungible wealth as perfect substitutes. First, the social security program provides an annuity rather than a fixed sum at retirement. Even before price indexing was formally incorporated in 1972, benefits were periodically adjusted for rising prices. Because of this "real annuity" character of social security, risk-averse individuals might reasonably regard a dollar of social security wealth as a substitute for more than a dollar's worth of fungible assets. Alternatively, since "social security wealth" lacks the liquidity of ordinary savings, a dollar of social security wealth might substitute for less than a dollar's worth of fungible assets. Second, social security benefits are not a contractual obligation of 
the government but are determined by legislation. Pessimists might therefore underestimate the value of social security wealth while optimists overestimate it. Finally, social security is not an actuarially fair program but alters lifetime budget constraints ; such changes in real lifetime resources will alter consumption and saving.

The implication of the theoretical issues that $I$ have been discussing is that the question of whether social security increases or decreases capital accumulation cannot be answered from theoretical consideration alone. The basic life cycle model suggests a strong presumption in favor of the conclusion that the unfunded social security program depresses national saving. But the possibility of irrational behavior by some individuals, the induced earlier retirement and changes in private intergenerational transfers, the role of unfunded private pensions, and the special characteristics of social security wealth all imply that the promise of social security benefits may not cause an equivalent reduction in private wealth accumulation. Only by the analysis of data on private saving and wealth can we hope to assess the actual effect of social security.

\section{Econometric evidence on the effect of social security on saving}

Economists are now beginning to use different bodies of data to estimate the impact of social security on saving. In the remaining part of this lecture, I will summarize some of the major findings of that econometric research. I will focus this necessarily brief summary on the studies dealing with the United States and on my own research. I hardly need say that empirical findings for the United States economy should not be extrapolated to other countries where differences in institutions could result in a quite different response to social security.

\subsection{The time series evidence}

During the late 1930's and the succeeding war years, there was a general expectation among economists that the saving rate would continue to rise as people became more affluent and as retirement at age 65 became increasingly common. That increase in saving did not materialize. Even as incomes rose very substantially in the 1960 's and the fraction of men over 65 who were still working dropped to less than half of the rate in the 1920 's, the aggregate saving rate did not increase significantly. This was also the period in which social security was introduced and in which it grew rapidly. It is worth noting that early American Keynesians like Seymour Harris [1941] and even Keynes himself ${ }^{2}$ predicted that the U.S. social security program precluded the rapid growth of private saving. Time series analysis of aggregate saving behavior permits a test of this view and, more generally, an estimate of the effect of changes in the level and scope of the social security program.

The basic problem in doing such time series analysis is measuring the magnitude of the social security program in a way that corresponds most closely to its potential effect on private saving. Surveys confirm that individuals do not have precise estimates of the likely value of their future social security benefits. Although legislative changes

2 My colleague Richard Musgrave recalls the occasion when Lord Keynes visited the U.S. Treasury and commented that the new U.S. Social Security program would prevent the excess saving that many economists then feared. 
create benefit entitlements immediately, these new benefits are only recognized slowly by the individuals affected. There is no completely satisfactory solution to this problem. In practice, all of the researchers have used "social security wealth," i.e., the present actuarial value of the future benefits to which the working population is entitled. ${ }^{3}$ This overly precise measure cannot provide an accurate picture of year to year variations in the public's perception of the extent to which they can rely on social security but, hopefully, it does capture the broad sweep of changes including the original introduction, the major extensions of coverage and the provision of dependents' benefits.

When a social security wealth variable is added to a standard aggregate consumption function that is estimated with annual data for the period 1929 through 1974 (without the 6 war years), its coefficient is 0,024 (with a standard error of 0,009).4 Adding this variable has relatively little effect on the coefficients of the other variables. Since the aggregate value of social security wealth in 1972 was $\$ 1.85$ trillion (Feldstein and Pellechio, 1979), a coefficient of 0.024 implies that social security increased consumption (and thereby depressed private saving) by $\$ 44.4$ billion. In 1972 , total private saving (including real corporate retained earnings) were $\$ 75.3$ billion. A reduction in saving of $\$ 44.4$ billion is thus equivalent to 59 percent of actual saving in 1972 .

With any statistical equation there is always the possibility that an estimated coefficient really reflects the effect of some important variable that has been inadvertently omitted. In the first time series study of this question (Feldstein, 1974), I tested the unemployment rate to assess whether the coefficient of the social security variable was only reflecting changes in unemployment rates between and within the pre-war and post-war periods. Including the unemployment rate had the effect of cutting the coefficient of the social security wealth variable by half (to 0.10 ) and to less than its standard error while the coefficient of the unemployment variable was slightly greater than its standard error. The problem of collinearity between the two series made it impossible to arrive at any firm conclusion unless the unemployment rate could be excluded on a priori grounds. Fortunately, shortly after the publication of my 1974 paper, the U.S. Department of Commerce published revised estimates of national income and its components which embody a number of improvements over the information that was previously available. Analysis with this new and better data eliminated the ambiguity previously introduced by unemployment. The unemployment variable became only a fraction of its standard error and its presence had almost no effect on either the coefficient of social security wealth or its statistical significance (Feldstein, 1979).

In an interesting extension of this analysis, Alicia Munnel [1974] added the retirement rate of men over age 65 as an additional variable. This specification makes the social security wealth coefficient a measure of the pure wealth replacement effect ; as expected, Munnel's coefficient of 0.30 is greater than my estimated net effect of 0.24 . The impact of induced retirement thus offsets an average of one-fifth of the pure wealth replacement effect of the traditional life cycle model.

3 The idea of social security wealth is introduced and described in Feldstein [1974].

4 This particular equation, presented in Feldstein [1979], is the same specification as reported in Feldstein [1974] but with a longer sample period and the new national income account revisions that were published in 1976. 
Robert Barro [1978] recently presented estimates that suggest that the effect of social security wealth is more ambiguous. His analysis modifies the basic specification of the consumption function by adding the government surplus as an additional variable. Barro's rationale for this novel specification is that a government surplus implies a reduction in government debt which, in an economy in which operative intergenerational transfers link all generations together, is equivalent to an increase in current disposable income. Adding the government surplus variable reduces the coefficient of social security wealth from 0.24 to 0.14 with a standard error of 0.10 . The depressing effect of social security appears to be smaller and statistically less significant.

I believe Barro's analysis is misleading. I have already explained why the assumption of an operational intergenerational transfer process is not likely to be a realistic description. More specifically, I believe the government surplus variable does not belong in a properly specified consumption function. Although the variable appears to be statistically significant, I believe that the significance is spurious. The government surplus is not an exogenous variable that directly affects consumption, as the Barro specification assumes, but an endogenous variable whose value changes with cyclical variations in consumption. What we really see in the positive coefficient of the government surplus variable is that an increase in consumer spending tends to expand the economy, raising tax collections and therefore increasing the government surplus. This interpretation is confirmed by dividing the surplus into its two components (government spending and tax receipts); the government expenditure variable is insignificant and the tax receipts variable is significant.

In concluding this summary of the time series evidence, I should note that data for the postwar period alone appear to be incapable of providing useful information on the effect of social security. In all of the studies using postwar data, the standard error of the coefficient of the social security wealth variable is so large that no economically interesting hypothesis can be rejected. This reflects not only the shorter period but also our inability to measure accurately enough the perceived changes in the public's expectation about future social security benefits. This inadequacy of the postwar data makes it important to examine other types of information, including cross-section data on individual households and cross-country studies of international differences in saving rates.

\subsection{Individual household evidence}

The best microeconomic data on the wealth of individual American households remains the Survey of Consumer Finances that was conducted in 1963 by the U.S. Census Bureau (Projector and Weiss, 1966). This survey of more than 2000 households greatly oversampled the high income population. On the basis of the information collected in the survey, I estimated the social security wealth of each household in the sample with a male between the ages of 35 and 64 .

In the first analysis of this data (Feldstein, 1976), I compared the characteristics of the distribution of ordinary "fungible wealth" with the characteristics of the distribution of "total wealth" (defined as the sum of ordinary fungible wealth and social security wealth). The key conclusion of that comparison is that the distribution of total wealth is much less concentrated than the distribution of ordinary fungible wealth. For example, while the top one percent of wealth holders had 28.4 percent of 
fungible wealth in 1963 , they only had 18.9 percent of total wealth. Since the concentration of ordinary wealth has shown no trend over the past 50 years, this evidence indicates a substantial reduction in the concentration of total wealth over this period.

This reduction in the concentration of total wealth is what would be expected because of the reduced concentration of disposable income over this century as well as the growing importance of estate taxes. This helps to resolve the apparent paradox of a stable concentration of wealth as conventionally measured and suggests that the concentration of fungible wealth has remained stable because of the growth of social security wealth.

Within each age group, the distribution of income among income classes is more similar to the distribution of total wealth than to the distribution of fungible wealth. The life cycle theory of wealth accumulation is thus more consistent with the distribution of total wealth than with the distribution of fungible wealth. This provides further indirect evidence that the prospect of social security benefits induces households to reduce their accumulation of private fungible wealth.

To test this relation between social security wealth and individual wealth accumulation more explicitly, Anthony Pellechio and I used these data to estimate the effect of each household's social security wealth on that household's pre-retirement accumulation of ordinary fungible wealth (Feldstein and Pellechio, 1979a). For this study, we limited our sample to households in which there was an employed man aged 55 to 64 ; households with very low or very high income were also eliminated. The basic parameter estimates indicated that social security substantially reduces the accumulation of household wealth as traditionally defined. More specifically, the point estimates generally indicate that each dollar of social security wealth reduces ordinary net worth by somewhat less than one dollar. The standard errors are too large to reject the implication of the traditional life cycle model that there is dollar-for-dollar replacement, but the estimates are also consistent with a rather wide range of other replacement rates. In general, however, the estimates are not compatible with the hypothesis that social security does not depress private wealth accumulation. This microeconomic evidence therefore supports the conclusion reached on the basis of the time series evidence.

New data on household wealth and on social security are just becoming available at this time. These new data represent substantially larger samples and contain information on potential social security benefits based on administrative records. They will therefore provide important opportunities to refine the existing analysis of household behavior.

\subsection{International evidence}

I turn finally to the evidence on the relation between international differences in social security and the saving rates in the corresponding countries. As I noted at the beginning of my talk, there are very substantial and relatively stable differences in saving rates. There is also substantial variation in the extent of social security coverage and in the ratio of social security benefits to income. More specifically, in a study of fifteen countries for which data could be compiled, I found that benefits per aged individual averaged 40 percent of per capita income during the period from 1954 
through 1960 and that the standard deviation of this ratio was 26 percent of per capita income (Feldstein, 1977).

To assess the effect of these differences in social security benefits, I used data on this cross-section of countries to estimate a model of the saving and retirement behavior implied by the extended life cycle theory. The savings function in this model builds on earlier studies of international savings differences by Houthakker $[1961,1965]$ and Modigliani [1970]. The basic life cycle model implies that a country's saving depends on the growth rate of aggregate income and the demographic structure of the population. To this specification I added an estimate of the ratio of social security benefits to average per capita income and a measure of retirement behavior.

The parameter estimates of this model imply that social security has a powerful effect on both saving and retirement. More specifically, if the retirement rate is held constant, an increase in the social security benefit ratio from one standard deviation below the sample average to one standard deviation above implies a reduction in the net private saving rate by 5.4 percentage points or 43 percent of the sample mean rate of saving. This overstates the net impact of social security on saving because an increase in social security benefits reduces the labor force participation of older men which in turn increases the saving rate. In the reduced form of the model, with the retirement rate no longer held constant, the net effect of social security on saving is some 80 percent of this pure wealth replacement value ; i.e., an increase in benefits from one standard deviation below the average to one standard deviation above reduces the saving rate by 4.3 percentage points.

One of the most worrisome things about the data used in the study is the crude measure of the social security benefits that employees expect. The observed ratio of actual benefits per aged individual to average per capita income may reflect past practices and previous income levels. A new set of data, produced by the U.S. Social Security Administration in cooperation with officials of foreign governments, provides measures of the actual statutory ratio of benefits to the preretirement earnings of typical employees in twelve countries (Olsen, 1978). I have been studying these data in the context of the extended life cycle model. Although this study is not yet complete, the coefficient estimates appear to confirm the results obtained with the cruder measure of social security benefits. It is quite reassuring that, despite the obvious problems of international comparability, the data appear to be rich enough to yield estimates of the impact of social security that are similar in magnitude to the estimates obtained with time-series data and with individual household observations.

\section{Conclusion}

This brings to an end my review of the theoretical and empirical analysis of the relation between social security and private saving. There will undoubtedly be further research on this subject in the future. New data and new conceptual insights will refine and could modify significantly the conclusions that emerge from existing research. Additional studies for other countries can indicate the extent to which they share the experience of the United States.

In my opinion, the existing research indicates that social security does substantially depress private saving and therefore national saving in the United States. Each dollar 
of social security wealth appears to reduce private wealth accumulation by somewhat less than a dollar but more than 50 cents. These studies have also contributed to our understanding of the basic process of saving and capital formation, showing the explanatory power and appropriateness of the life cycle framework as well as the need to extend the traditional life cycle model to a less restricted form of behavior. The more general lesson about the importance of the unintended but adverse consequences of a well-meaning government policy should also not go unnoticed.

\section{REFERENCES}

ANDO, A., and MODIGLIANI, F. [1963]: "The 'Life Cycle' hypothesis of saving: Aggregate implications and tests", American Economic Review, 53, 55-84.

BARRO, R. [1974] : “Are government bonds net wealth?”, Journal of Political Economy, $82,1095-1117$.

BARRO, R. [1978]: "The impact of social security on private saving”, The American Enterprise Institute Studies, 199.

CAGAN, P. [1965]: The Effect of Pension Plans as Aggregate Savings, New York, National Bureau of Economic Research.

FELDSTEIN, M. [1974] : “ Social security, induced retirement and aggregate capital accumulation ", Journal of Political Economy, 82, 905-926.

FELDSTEIN, M. [1976] : "Social security and the distribution of wealth", Journal of the American Statistical Association, 71, 800-807.

FELDSTEIN, M. [1977] : “ Social security and private savings : International evidence in an extended life cycle model", in Feldstein and Inman (eds.), The Economics of Public Services, New York, Halsted Press.

FELDSTEIN, M. [1978]: “Do private pensions increase national saving?", Journal of Public Economics, 10, 277-293.

FELDSTEIN, M. [1979] : "The effect of social security on private saving: The time series evidence", National Bureau of Economic Research, working paper 314.

FELDSTEIN, M., and BERNHEIM, B. [1979]: “The empirical irrelevance of intergenerational transfers for the effects of social security and government deficits", forthcoming.

FELDSTEIN, M., and HORIOKA, C. [1979] : "Domestic savings and international capital flows", National Bureau of Economic Research, working paper 310.

FELDSTEIN, M., and PELLECHIO, A. [1979] : "Social security wealth and the impact of alternative inflation adjustments", in C. Campbell (ed.), Social Security, forthcoming.

FELDSTEIN, M., and PELLECHIO, A. [1979a] : "Social security and household wealth accumulation: New microeconometric evidence", Review of Economics and Statistics, 61, 361-368.

FELDSTEIN, M., and SELIGMAN, S. [1979] : “The effect of unfunded pension liabilities on share prices", forthcoming.

FISHER, I. [1930]: The Theory of Interest, New York, Mac Millan.

HARRIS, S. [1941] : The Economics of Social Security, New York, McGraw-Hill.

HARROD, R. [1948] : Towards a Dynamic Economics, London, Mac Millan. 
HOUTHAKKER, H. [1961] : “An international comparison of personal saving”, Bulletin of the International Statistical Institute, 38, 56-59.

HOUTHAKKER, H. [1965] : "On some determinants of saving in developed and underdeveloped countries ", in E. Robinson (ed.), Problems of Economic Development, London, Mac Millan, chap. 10.

KATONA, G. [1965] : "Private pensions and individual saving”, Institute for Social Research, the University of Michigan.

KOCHIN, L. [1974]: “Are future taxes anticipated by consumers", Journal of Money, Credit and Banking, 6, 385-394.

MEYERS, R. [1965] : Social Insurance and Allied Government Programs, Homewood (Ill.), Irwin.

MILLER, M., and UPTON, C. [1974] : Macro-economics : A Neo-classical Introduction, Homewood (Ill.), Irwin.

MODIGLIANI, F. [1966]: "The life cycle hypothesis of saving, the demand for wealth and the supply of capital ", Social Research, 33, 160-217.

MODIGLIANI, F. [1970] : "The life cycle hypothesis of saving and intercountry differences in the saving ratio", in W. A. Eltis (ed), Induction, Growth and Trade, Essays in Honor of Sir Roy Harrod, Oxford University Press.

MODIGLIANI, F., and ANDO, A. [1957]: "Test of the life cycle hypothesis of saving", Bulletin of the Oxford University Institute of Statistics, 19, 99-124.

MODIGLIANI, F., and BRUMBERG, R. [1954]: "Utility analysis and the consumption function: An interpretation of cross-section data ", in K. Kurihara (ed.), Post Keynesian Economics, New Brunswick (N.J.), Rutgers University Press, 388-436.

MUNNEL, A. [1974] : The Effect of Social Security on Personal Saving, Cambridge, Ballinger.

OLDFIELD, G. [1977] : "Financial aspects of the private pension system", Journal of Money, Credit and Banking, 9, 48-54.

OLSEN, L. H. [1978] : “Earnings-replacement rate of old-age benefits, 1965-1975, selected countries", Social Security Bulletin, 41, 3-14.

PECHMAN, J., AARON, H., and TAUSSIG, M. [1968] : Social Security - Perspectives for Reform, Washington, Brookings Institution.

PROJECTOR, D., and WEISS, G. [1966] : Survey of Financial Characteristics of Consumers, Washington, Board of Governors of the Federal Reserve System.

SAMUELSON, P. [1958] : "An exact consumption-loan model of interest with or without the social contrivance of money", Journal of Political Economy, 66, 467-482.

SCHULZ, J. et al [1974] : Providing Adequate Retirement Income: Pension Reform in the United States and Abroad, Hanover (New Hamp.), published for Brandeis University Press by the University Press of New England.

WINTWORTH, F., and MOTLEY, D. [1970] : Resources After Retirement, Social Security Administration, Office of Research and Statistics Research Report No. 34 - Washington, U.S. Government Printing Office. 